\title{
Patterns of Structural Change in the NeW EU MEMbER STATES
}

\author{
Peter Havlik $^{1}$
}

\begin{abstract}
This paper analyses the extent and impact of structural changes on aggregate economic growth that occurred in European economies during the past two decades, focusing on the new EU Member States of Central and Eastern Europe. After presenting some stylised facts related to employment and output restructuring, we use a conventional shift and share analysis in order to evaluate the impact of broader sectoral shifts on GDP growth, focusing on the period 1995-2011. A decomposition of aggregate GDP/GVA growth using the shift and share analysis shows a distinct North-South pattern of growth and restructuring while the previous NMS-OMS divisions are becoming less relevant. In the North, manufacturing and trade have fuelled growth whereas in the South there has been much less structural change. Apart from these differences, our results partly differ from earlier findings of similar analyses for the NMS. Finally, we analyse differentiated impacts of the recent (2008-2011) crisis on structural changes in Europe and find interesting similarities between (groups of) NMS and OMS in terms of both growth patterns and responses to the crisis.
\end{abstract}

\section{Keywords}

Economic Restructuring, Growth, Output, Employment, Crisis

\section{Introduction}

The aim of this paper is to examine the extent and patterns of structural changes that have recently occurred in European economies, in particular in the new EU Member States of Central and Eastern Europe (NMS). Before examining the effects of structural change on aggregate economic growth, some stylised facts on changing output and employment structures are provided. The next step is an analysis of growth decomposition using the 'shift-and-share' analysis, focusing on the period after 1995 and, last but not least, on the

\footnotetext{
${ }^{1}$ Vienna Institute for International Economic Studies, wiiw, Rahlgasse 3, 1060 Vienna, Austria. E-mail: ha-
} vlik@wiiw.ac.at. 
crisis period 2008-2011. The standard hypothesis of the growth-accounting literature is that structural change is an important source of economic growth and overall productivity improvements (Maddison, 1987). This hypothesis assumes a surplus of labour in some (less productive) parts of the economy (such as agriculture), thus shifts towards higherproductivity sectors (industry) are beneficial for aggregate economic growth. Even within industry, shifts towards more productive branches should boost aggregate productivity. On the other hand, structural change may have a negative impact on aggregate productivity growth if labour shifts to industries with slower productivity growth (parts of the services sector, in particular non-market services). The 'structural bonus and burden' hypothesis (Baumol, 1967) was examined on the example of Asian economies by Timmer and Szirmai (2000), on a large sample of OECD and developing countries (Fagerberg, 2000), and more recently by Peneder (2003) for the United States, Japan and the EU Member States as well as by Havlik (2005a) and Havlik, Leitner and Stehrer (2012) for the CEE countries. A lot of attention has also been devoted to the analysis of patterns and causes of varying productivity performance between the EU and the United States, exploring in particular at detailed sectoral level the reasons for the EU's lagging behind (Timmer, Inklaar, O'Mahony and van Ark, 2010; van Ark, O'Mahony and Timmer, 2012).

All these latter studies have failed to confirm the general validity of the structural bonus hypothesis but did find some evidence for negative productivity effects of structural change. In particular, van Ark et al. (2012) show that slow productivity growth in market services has been characteristic of the EU but not of the USA. In the pre-crisis period 1995-2007, they find that especially trade, finance and business services have boosted US productivity growth in market services relative to the West European EU countries. Similarly, Timmer et al. (2010, p. 34) find that the 'EU-US productivity gap since the mid-1990s has mainly been located in market services. Contrary to Baumol's cost-disease hypothesis, labour productivity growth in some service industries has been strong, particularly in the USA'. Transatlantic growth differences were especially large in distributive trade and in business services (ibid., p. 11). In contrast, Havlik et al. (2012) found that, in selected CEE countries (the Czech Republic, Hungary, Poland, Slovakia and Slovenia), high productivity growth rates were achieved in manufacturing industries rather than in services during the same period.

The Central and East European new EU Member States (NMS) have experienced important changes during their transition to market economies. One aspect of these changes in the course of transition is reflected in the far-reaching restructuring of both production and employment patterns. ${ }^{2}$ This paper first illustrates these changes with stylised facts related to NMS output and employment structures during the period 1995-2011 at broader sectoral levels (Section II), focusing particularly on restructuring patterns during the recent crisis (2008-2011). Section III attempts to find out whether there has been a process of structural convergence towards the more advanced EU countries during the two decades of economic transition and integration with the EU. Section IV evaluates the impact of structural changes on aggregate growth with the help of a conventional shift and share analysis. Section V

${ }^{2}$ Another structural feature of transition has been regional and commodity trade restructuring - see Dobrinsky and Landesmann (1995), Havlik (2008). 
provides a summary of findings and some policy recommendations related to the future role of the NMS in the economy of an integrated Europe, especially in view of post-crisis growth challenges.

\section{Basic patterns of changing output and employment structures}

The majority of NMS inherited a huge, oversized and inefficient industrial sector from the period of central planning. At the same time, the services sector - market services in particular - was grossly underdeveloped (Landesmann and Stehrer, 2002; Vidovic, 2002). In 1990, manufacturing industry value added accounted for around $40 \%$ of GDP in Bulgaria and Poland, for about 35\% of GDP in the Czech Republic, Romania, Slovakia and the Baltic States, but for less than $30 \%$ of GDP in Slovenia and only 20\% in Hungary (Figure 1). ${ }^{3}$ Due to considerable structural distortions and production inefficiencies, a high degree of industrialisation initially turned out to be a drawback rather than an advantage: it also implied, among other problems, the underdevelopment of other sectors, especially of services. In all NMS countries, industry suffered over-proportionally from the 'transformational recession' at the beginning of transition. The time pattern of this recession varied, largely depending on the date when transformation measures were initiated. In Central and Eastern Europe, the transformational recession started already in 1989/1990 with huge output declines (by about 15\% per year) and continued well into 1992/1993. In the Baltic States, the full impact of the crisis came with a delay of approximately two years, and was aggravated by the dissolution of the USSR in 1992.

Despite some recovery after 1993 (largely thanks to Poland), the cumulative decline of industrial output between 1990 and 1995 still amounted to nearly $10 \%$ in Central and Eastern Europe (CEEC-7) and to more than 50\% in the three Baltic States (Havlik, 2005a). Industry, and especially its manufacturing part, also shrank in relative terms during this period (with the sole exception of Hungary). Poland and Romania have managed to keep the share of manufacturing value added in GDP nearly constant during the past decade - see Figure 1). ${ }^{4}$ In Bulgaria and Poland, the share of manufacturing in GDP initially dropped by some 20 percentage points (pp) between 1990 and 1995; in the remaining countries this share dropped by 'only' $10-15 \mathrm{pp}$. A number of factors, such as the loss of traditional export markets, sudden trade liberalisation, restrictive macroeconomic policies and insufficient restructuring played a role. The relative decline of industry naturally went hand in hand with an expansion of services that had been grossly underdeveloped under the old system.

By 2011, only the Czech Republic and Romania had a manufacturing industry with a share of more than $20 \%$ of GDP - about the same as the two most industrialised 'old' EU Member States (OMS), Germany and Ireland. Among the OMS, only Germany and Portugal have succeeded in keeping the share of manufacturing in GDP more or less constant over the

\footnotetext{
${ }^{3}$ Unless otherwise stated, the wiiw Annual Database, which relies on national statistics, and Eurostat are used as the main source of data. Data for the early 1990s are not fully comparable with later periods due to changes in classifications.

${ }^{4}$ Due to frequent changes in statistical reporting and varying enterprise coverage, data for the first half of the 1990s are both less reliable and not fully comparable with later periods.
} 
past two decades (at 20\% and 15\% of GDP, respectively); in all other OMS manufacturing shrank considerably over this period (Figure 1).

Figure 1: Manufacturing value added in \% of GDP

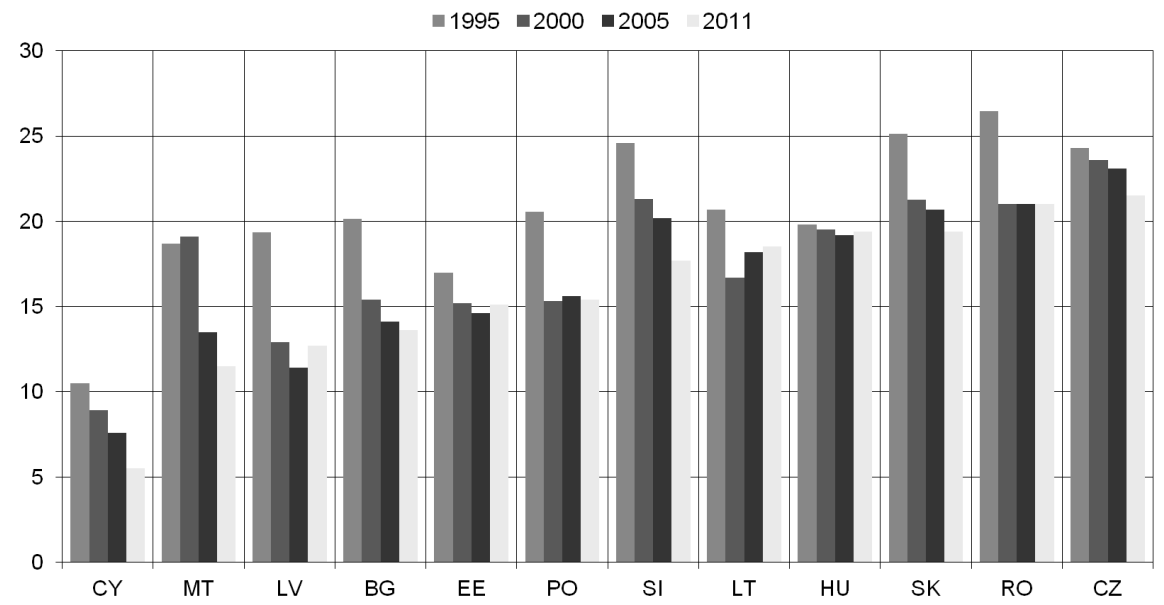

Note: Countries ranked according to the share of manufacturing in 2011.

Source: Own calculations based on wiiw Database and Eurostat

Figure 2: Manufacturing employment in \% of total

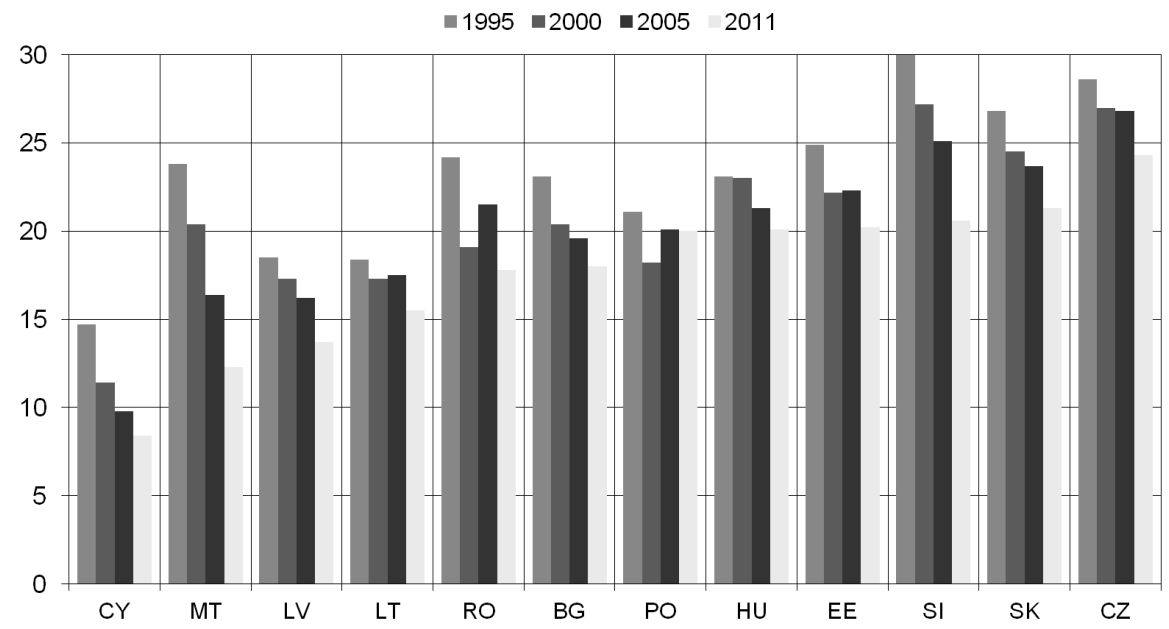

Note: Countries ranked according to the share of manufacturing in 2011.

Source: Own calculations based on wiiw Database and Eurostat

In several NMS (Hungary, Poland, Romania and the Baltic States), the manufacturing industry managed to recover at least part of its previous position starting from the second half of the 1990s and thereafter, largely thanks to active restructuring and privatisation 
efforts, fostered especially by inflows of FDI. Nevertheless, in the year 2001 only Hungary and Poland produced more industrial output, by $60 \%$ and 70\%, respectively, than in 1990 . By contrast, in Bulgaria and Romania industry shrank by more than $30 \%$ during that period, in the Baltic States by half, while in the remaining NMS the cumulative output decline amounted to around 10\% (Havlik, 2008; we shall turn to the related structural changes below). During the 2000s, both industry and GDP continued to recover - though the recovery was uneven and was abruptly interrupted by the crisis in 2009 (wiiw, 2012). At the beginning of the 2010s, manufacturing industry still contributed a significant part to the GDP: the shares of manufacturing in GDP in the majority of NMS were higher than in West and South European EU Member States (European Commission, 2011 and Figure 1). In the EU-27 average, real estate, renting and business activities replaced manufacturing as the largest sector (in 2009, measured by sector shares in GDP - see European Commission, 2011, p. 55). On the global scale, manufacturing accounted for 17\% of GDP in 2010 (33\% in China, 28\% in South Korea, 20\% in Japan, 17\% in Mexico and 12\% in the United States - see McKinsey, 2012).

Figure 3: Differences in manufacturing industry shares: GVA vs employment, year 2011, in percentage points

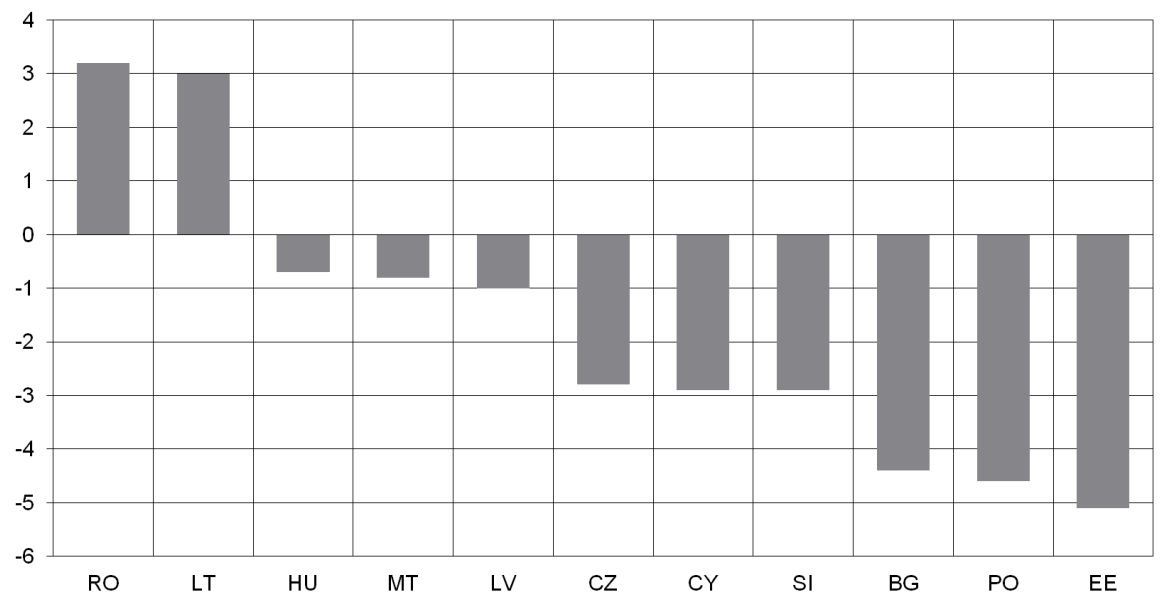

Source: Own calculations based on wiiw Database and Eurostat

NMS employment has undergone even more dramatic changes during the past two decades. As a rule, employment declined more than output and millions of jobs were lost in the region during the first transition decade. This reflected general labour market developments during the 1990s, such as declining overall employment, shifts from industry to the services sector and, last but not least, the emergence of open unemployment. ${ }^{5}$ In the second half of the 1990s, only Hungary (and partly also Poland) could modestly increase manufacturing industry employment; in the remaining candidate countries manufacturing

\footnotetext{
${ }^{5}$ For more details on labour market developments during the 1990s, see Vidovic (2002); European Commission - Eurostat (1999).
} 
employment continued to fall. Employment adjustments occurred with a certain time lag after changes in output, first due to delayed lay-offs and hardly any expansion of manufacturing jobs thereafter (again in both absolute and relative terms). Another labour market shock occurred as a consequence of the crisis in 2009 and afterwards. Still, manufacturing industry remains an important job provider in many NMS; the highest employment shares in the manufacturing industry were observed in the Czech Republic (nearly $25 \%$ of total employment - see Figure 2). In all NMS bar Latvia, and despite a relative decline in importance as a job provider, manufacturing jobs account for more than $15 \%$ of the total.

An associated feature of diverging developments in output and employment shares has been impressive productivity in terms of catching up. During the period 1995-2007, the difference in the growth of labour productivity between NMS (Czech Republic, Hungary, Poland, Slovakia and Slovenia) and the EU-15 was about 3-5 pp per year (Havlik et al., 2012, p. 243). In relative terms, Bulgaria, Estonia and Poland have the most 'labourintensive' manufacturing industry among the NMS (approximated by differences in shares of gross value added and employment in total) while Romania and Lithuania are the least labour-intensive (Figure 3). ${ }^{6}$

\section{Structural change in GDP and employment}

\section{GDP and gross value added}

The above changes in the importance of manufacturing obviously mirror the shifts in the importance of other economic sectors. In order to evaluate the overall pace and patterns of structural change, we use the structural change indicator $\mathrm{S}$, which measures aggregate shifts in sectoral shares. ${ }^{7}$ Table 1 provides the results for changes in the structure of EU countries' GDP (gross value added), separately for the whole period 1995-2011 for which comparable data are available, as well as for the three five-year sub-periods and the most recent period of the crisis (2008-2011). Unfortunately, the results are not very conclusive, as no clear pattern in the speed of structural change can be discerned. This may result partly from different data availability details and varying phases of structural adjustments in individual countries but, in general, it also reflects different speeds of restructuring in individual countries and sub-periods.

\footnotetext{
${ }^{6}$ Needless to say, these differences are affected by the sectoral structure of manufacturing branches and their varying capital intensity.

${ }^{7}$ The structural change indicator S is calculated from 1-digit NACE Rev. 1 resp. NACE Rev. 2 data for sectoral gross value added (at current prices) and employment using the formula:

$$
\begin{aligned}
S^{*} & =\sqrt{\sum_{k}\left(s h_{k}^{t_{2}}-s h_{k}^{t_{1}}\right)^{2} \cdot\left(s h_{k}^{t_{1}} / 100\right)} \\
k & =\text { individual NACE Rev. } 1 \text { resp. NACE Rev } 2 \text { sector } \\
s h_{k} & =\text { share of sector } k \text { in total output or employment (in \%) } \\
t_{i} & =\text { time index, where } i \text { denotes different years. }
\end{aligned}
$$
}


Generally, it seems that structural change has been more pronounced in Bulgaria, Romania and in the Baltic States than in the Czech Republic, Hungary, Estonia or Poland. Furthermore, the 'earlier' period 1995-2000 experienced more restructuring than the period immediately before EU accession (2000 2005), and the most recent period 2005-2011 is in several countries characterised by more restructuring than before accession (e.g. Czech Republic, Slovakia and Slovenia). The latter period was also affected by the recent crisis which, as a rule, hit manufacturing, construction and tradable services much harder than other sectors (Hanzl-Weiss and Landesmann, 2013).

In the crisis period (2008-2011), Romania, Latvia, Lithuania and Bulgaria experienced the most structural change, whereas the output structures of the Czech Republic and Poland remained most stable (for detailed sectoral patterns, see below).

A more detailed picture of structural change patterns over the whole period 1995-2011 is provided by Figures 4 and 5, which shows sectoral changes of gross value added in percentage points for individual countries. Despite the existence of country-specific restructuring patterns (and different classifications due to data availability constraints), several stylised facts common to most countries emerge: the output shares of agriculture and manufacturing usually declined during that period, whereas those of real estate, renting and business activities, information and communication, financial and insurance services as well as of public administration increased. Generally, however, restructuring patterns were highly diverse across individual countries (Figures 4 and 5).

Table 1: GDP/GVA structural change (S-indicator, calculated from NACE Rev. 2 data)

\begin{tabular}{|l|ccccc|}
\hline NMS & \multicolumn{5}{|c|}{ Period } \\
\hline BU-N2 & $2011-1995$ & $2011-2005$ & $2005-2000$ & $2000-1995$ & $2011-2008$ \\
& 4.608 & 1.447 & 1.847 & 4.414 & 1.538 \\
\hline CZ-N2 & $2011-1995$ & $2011-2005$ & $2005-2000$ & $2000-1995$ & $2011-2008$ \\
& 0.847 & 0.844 & 0.457 & 1.372 & 0.322 \\
\hline EE-N2 & $2011-1995$ & $2011-2005$ & $2005-2000$ & $2000-1995$ & $2011-2008$ \\
& 1.444 & 1.375 & 1.291 & 1.303 & 1.252 \\
\hline HU-N2 & $2011-1995$ & $2011-2005$ & $2005-2000$ & $2000-1995$ & $2011-2008$ \\
& 1.309 & 0.547 & 0.598 & 1.037 & 0.607 \\
\hline LV-N2 & $2011-1995$ & $2011-2005$ & $2005-2000$ & $2000-1995$ & $2011-2008$ \\
& 2.969 & 1.775 & 1.180 & 3.216 & 2.013 \\
\hline LT-N2 & $2011-1995$ & $2011-2005$ & $2005-2000$ & $2000-1995$ & $2011-2008$ \\
& 2.811 & 0.870 & 1.188 & 1.530 & 1.913 \\
\hline PL-N2 & $2011-1995$ & $2011-2005$ & $2005-2000$ & $2000-1995$ & $2011-2008$ \\
& 1.512 & 0.471 & 0.609 & 1.490 & 0.335 \\
\hline RO-N1 & $2009-1995$ & $2009-2005$ & $2005-2000$ & $2000-1995$ & $2011-2008$ \\
& 5.686 & 1.247 & 1.141 & 3.853 & 2.41 (N2) \\
\hline SI-N2 & $2011-1995$ & $2011-2005$ & $2005-2000$ & $2000-1995$ & $2011-2008$ \\
& 1.939 & 1.171 & 0.695 & 0.686 & 0.830 \\
\hline SK-N2 & $2011-1995$ & $2011-2005$ & $2005-2000$ & $2000-1995$ & $2011-2008$ \\
& 2.219 & 1.150 & 0.940 & 1.259 & 0.809 \\
\hline
\end{tabular}




\begin{tabular}{|l|ccccc|}
\hline NMS & \multicolumn{5}{|c|}{ Period } \\
\hline CY-N2 & $2011-1995$ & $2011-2005$ & $2005-2000$ & $2000-1995$ & $2011-2008$ \\
& 2.369 & 1.355 & 1.273 & 1.004 & 1.746 \\
\hline MT-N1 & $2010-1995$ & $2010-2005$ & $2005-2000$ & $2000-1995$ & $2011-2008$ \\
& 4.084 & 1.821 & 2.765 & 1.043 & 1.175 \\
\hline
\end{tabular}

Source: Own calculations based on Eurostat

Figure 4: Structural change - shares in GDP (in percentage points) NACE Rev. 2

Hungary, 2011-1995, N2

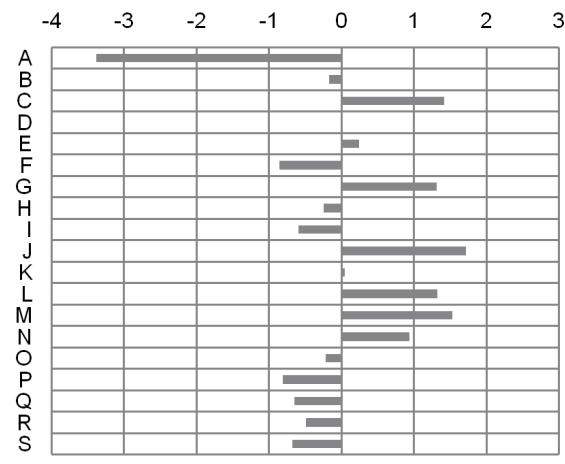

Slovenia, 2011-1995, N2

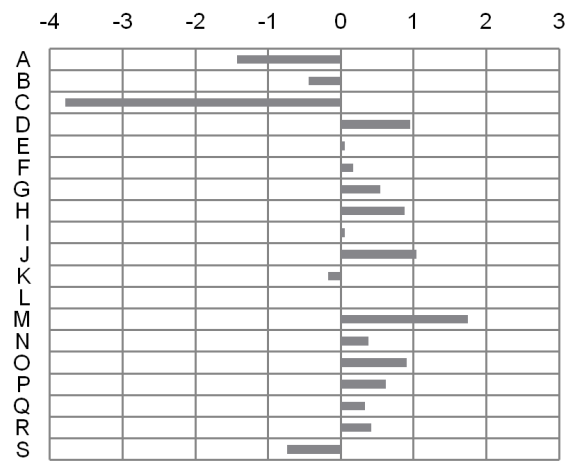

Note: See Annex for NACE sectoral codes.

Source: wiiw calculations based on Eurostat
Poland, 2011-1995, N2

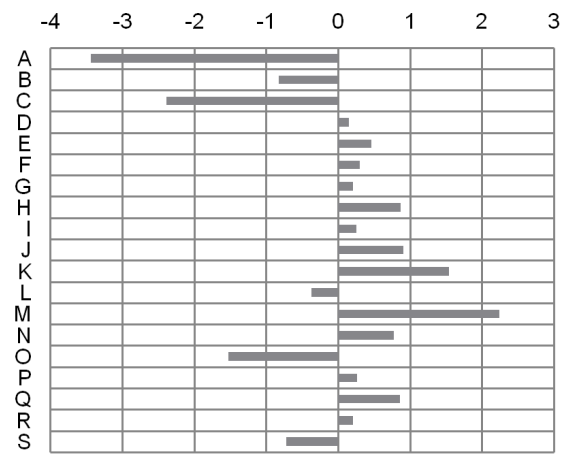

Slovakia, 2011-1995, N2

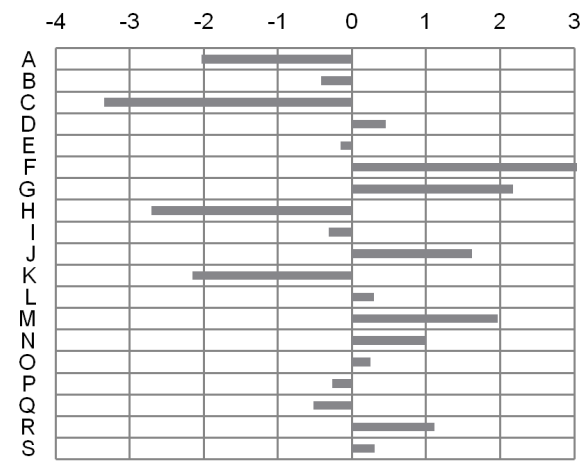


Figure 5: Structural change - shares in GDP (in percentage points) NACE Rev. 2

Lithuania, 2011-1995, N2

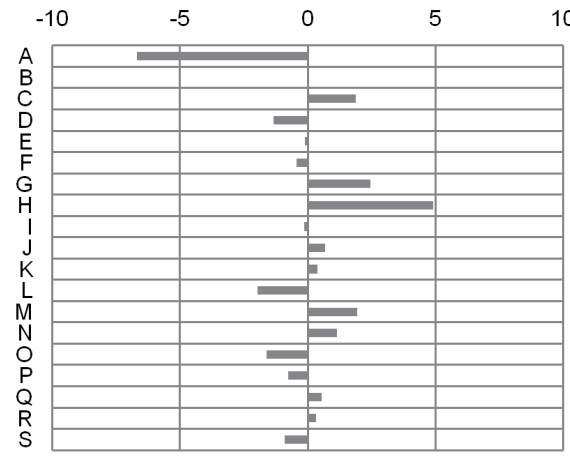

Estonia, 2011-1995, N2

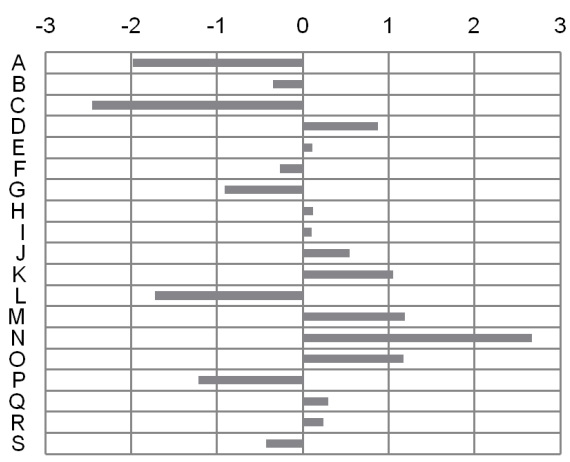

Romania, 2009-1995, N1

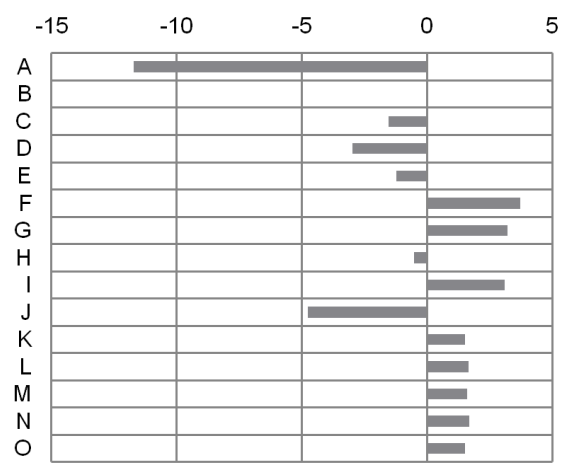

Note: See Annex for NACE sectoral codes. Source: wiiw calculations based on Eurostat
Latvia, 2011-1995, N2

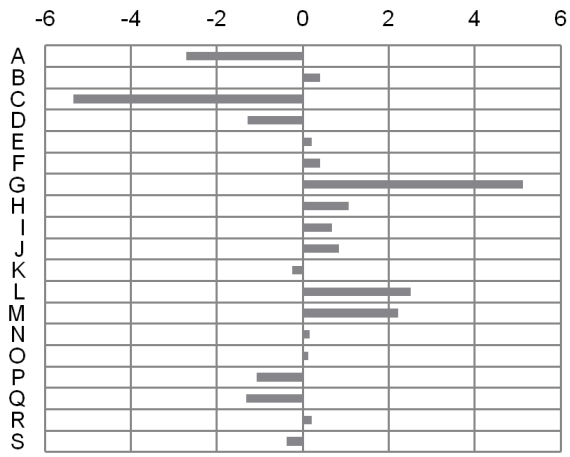

Czech Republic, 2011-1995, N2

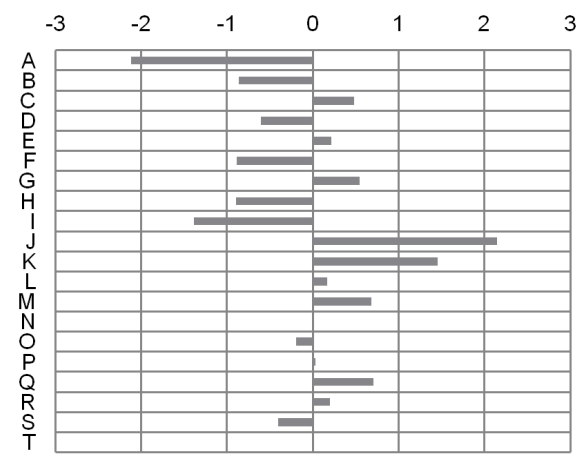

Bulgaria, 2011-1995, N2 (A10)

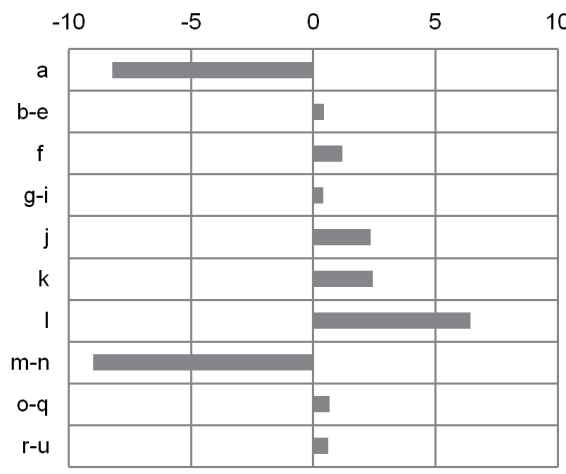


A number of distinct interesting features of restructuring emerged during the crisis period 2008-2011. Apart from a certain revival of manufacturing (e.g. in the Baltic States and in Hungary), it was mostly construction and trade which suffered from declining value added shares during the crisis in a number of NMS (Figures 6 and 7). Structural change was least pronounced in the Czech Republic during this period. In Poland - the only EU country which did not experience a decline in GDP during the crisis period - a certain return to a 'traditional' pattern of restructuring occurred as a number of 'productive' sectors (energy, construction and trade) managed to increase their shares in GDP while the shares of information, communication services and especially financial services declined (Figures 6 and 7).

Figure 6: Structural change - shares in GDP (in percentage points) NACE Rev. 2
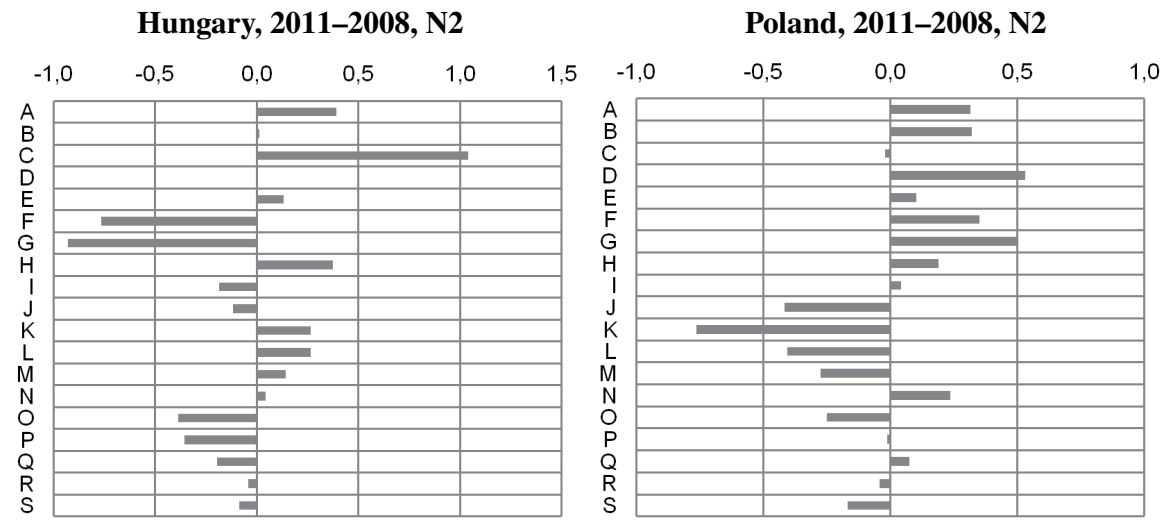

Slovakia, 2011-2008, N2
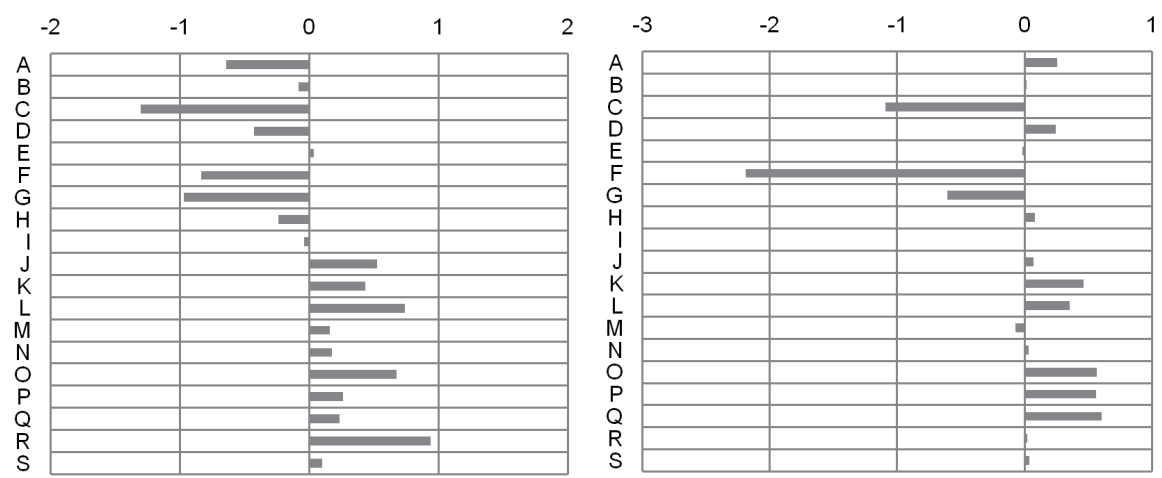

Note: See Annex for NACE sectoral codes.

Source: wiiw calculations based on Eurostat 
Figure 7: Structural change - shares in GDP (in percentage points) NACE Rev. 2

Lithuania, 2011-2008, N2

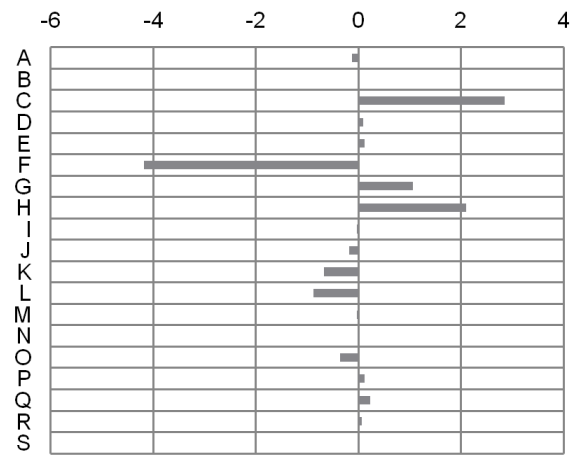

Estonia, 2011-2008, N2

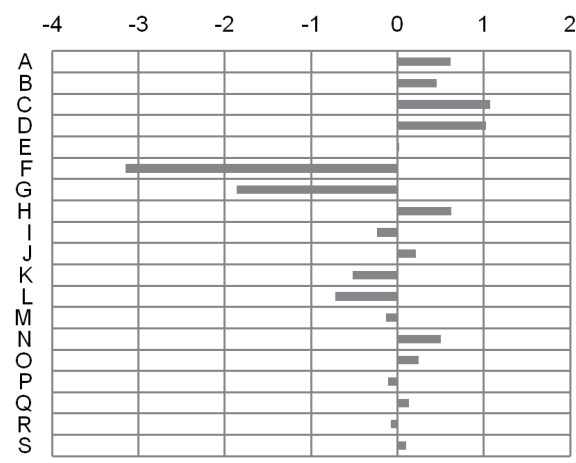

Romania, 2011-2008, N2

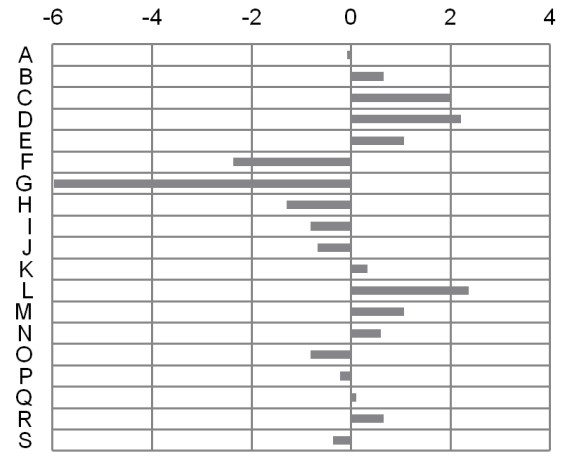

Note: See Annex for NACE sectoral codes.

Source: wiiw calculations based on Eurostat
Latvia, 2011-2008, N2

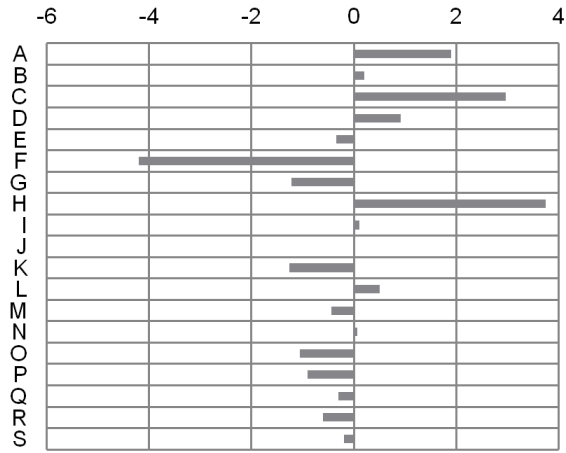

Czech Republic, 2011-2008, N2

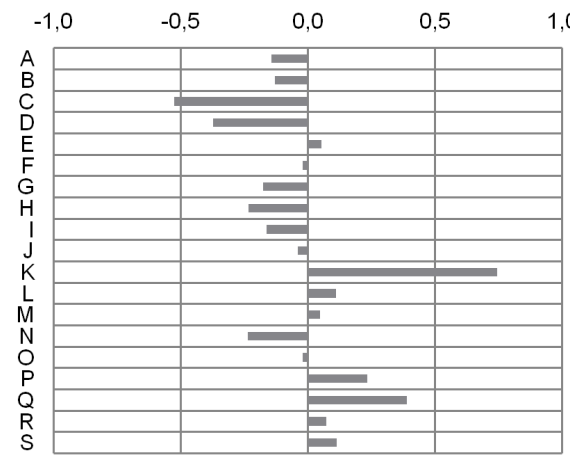

Bulgaria, 2011-2008, N2 (A10)

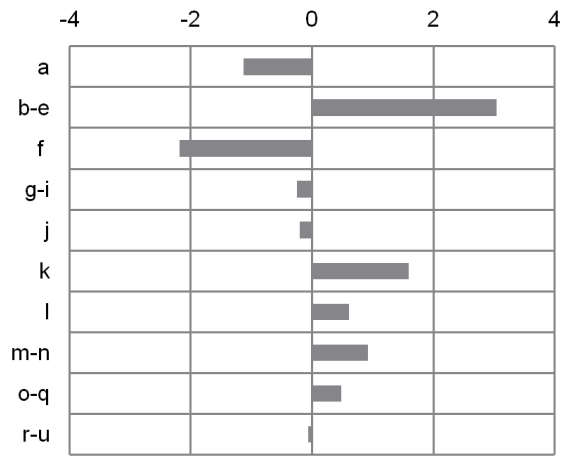




\section{Structural changes in employment}

Structural change indicators for employment (number of employed persons) are presented in Table 2, again separately for the whole period 1995-2011 and individual sub-periods. Detailed data availability again differs across countries; comparable employment data (employed persons) for the whole period are not available for Latvia, Bulgaria and Romania as well as for a number of OMS. The Czech Republic has experienced the least structural change in terms of employment among the EU Member States; with the contrast to Slovakia, Slovenia and Hungary being especially interesting. There is no clear pattern across individual sub-periods: in the majority of countries, the employment restructuring process was more or less evenly distributed across the whole 1995-2011 period and the structural change indicators do not differ in individual sub-periods.

In the most recent crisis period (2008-2011), ${ }^{8}$ the employment structure in Hungary (and Malta) changed very little. In the remaining countries, especially in the Baltic States and in Romania, employment structures changed much more during the crisis (Table 2).

Table 2: Employment structural change (S-indicators)

\begin{tabular}{|c|c|c|c|c|c|}
\hline NMS & \multicolumn{5}{|c|}{ Period } \\
\hline \multirow[t]{2}{*}{ BG-N2 } & 2011-1995 & 2011-2005 & $2005-2000$ & $2000-1995$ & 2011-2008 \\
\hline & 4.588 & 1.614 & 2.072 & 2.061 & 1.110 \\
\hline \multirow[t]{2}{*}{ CZ-N2 } & $2011-1995$ & $2011-2005$ & $2005-2000$ & $2000-1995$ & 2011-2008 \\
\hline & 1.111 & 1.068 & 0.299 & 0.726 & 0.815 \\
\hline \multirow{2}{*}{ EE-N2 } & 2011-1995 & $2011-2005$ & $2005-2000$ & $2000-1995$ & 2011-2008 \\
\hline & 3.089 & 1.076 & 0.712 & 1.744 & 1.318 \\
\hline \multirow[t]{2}{*}{ HU-N2 } & 2011-1995 & $2011-2005$ & $2005-2000$ & $2000-1995$ & $2011-2008$ \\
\hline & 3.277 & 0.539 & 1.808 & 1.221 & 0.555 \\
\hline \multirow[t]{2}{*}{ PL-N2 } & 2011-1995 & $2011-2005$ & $2005-2000$ & $2000-1995$ & 2011-2008 \\
\hline & & 2.040 & & & 0.929 \\
\hline \multirow[t]{2}{*}{ LV-N2 } & $2011-2000$ & 2011-2005 & $2005-2000$ & $2000-1995$ & 2011-2008 \\
\hline & 2.538 & 1.614 & 1.545 & 1.016 & 1.911 \\
\hline \multirow[t]{2}{*}{ LT-N2 } & $2011-2000$ & $2011-2005$ & $2005-2000$ & $2000-1995$ & 2011-2008 \\
\hline & 4.690 & 2.463 & 2.312 & 1.016 & 1.582 \\
\hline \multirow[t]{2}{*}{ RO-N1 } & $2010-1996$ & $2010-2005$ & $2005-2000$ & $2000-1996$ & 2011-2008 \\
\hline & 7.384 & 4.932 & 9.124 & 7.886 & $1.369(\mathrm{~N} 2)$ \\
\hline \multirow[t]{2}{*}{ SK-N2 } & 2011-1995 & $2011-2005$ & $2005-2000$ & $2000-1995$ & 2011-2008 \\
\hline & 3.866 & 1.140 & 1.391 & 1.740 & 1.114 \\
\hline \multirow[t]{2}{*}{ SI-N2 } & 2011-1995 & $2011-2005$ & $2005-2000$ & $2000-1995$ & 2011-2008 \\
\hline & 5.679 & 2.350 & 1.368 & 1.801 & 1.297 \\
\hline \multirow[t]{2}{*}{ CY-N2 } & 2011-1995 & 2011-2005 & $2005-2000$ & $2000-1995$ & 2011-2008 \\
\hline & 2.698 & 0.843 & 0.853 & 1.455 & 0.781 \\
\hline \multirow[t]{2}{*}{ MT-N2 } & $2011-1995$ & $2011-2005$ & $2005-2000$ & $2000-1995$ & $2011-2008$ \\
\hline & 5.735 & 1.781 & 1.908 & 1.835 & 0.482 \\
\hline
\end{tabular}

Source: Own calculations based on Eurostat

${ }^{8}$ For this period there are comparable data for all countries in NACE Rev. 2 classification and 21 sectors (except France, Portugal and Spain). 
A closer look at sectoral employment adjustment patterns over the whole period 1995 to 2011 reveals significant declines in employment shares of agriculture (by up to $10 \mathrm{pp}$ in Lithuania and Romania) and of manufacturing (particularly in Slovenia and Malta), while trade and real estate, renting and business activities gained employment shares in most EU countries. In a number of NMS (Hungary, Latvia and Slovakia), employment in administrative and support services activities gained most in importance (Figures 8 and 9). During the crisis period 2008-2011, the most striking development was represented by the declining employment shares of manufacturing and construction in nearly all NMS (particularly in the Baltic States but with the exception of the Czech Republic and Poland - see Figures 10 and 11).

Figure 8: Structural change - shares in employment (in percentage points) NACE Rev. 2

Czech Republic, 2011-1995, N2

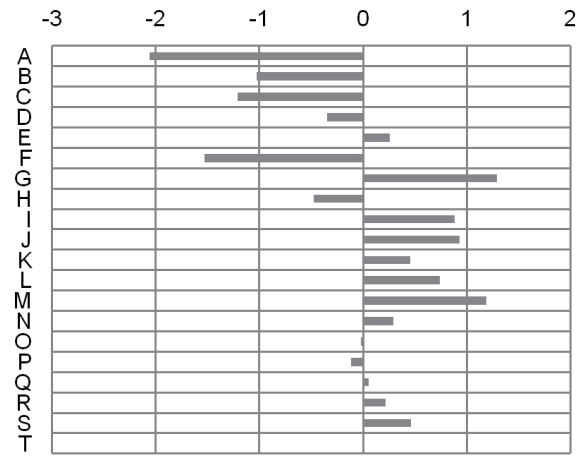

Latvia, 2011-2000, N2

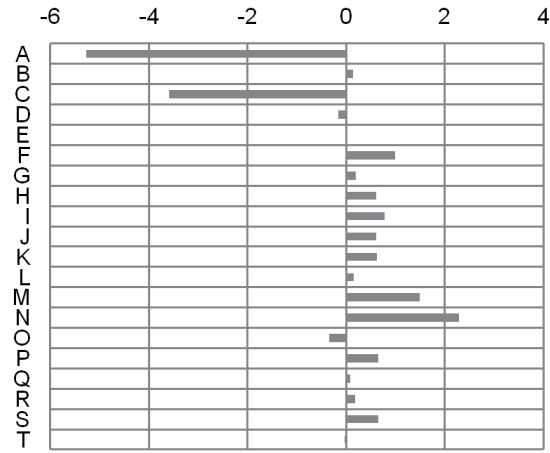

Estonia, 2011-1995, N2

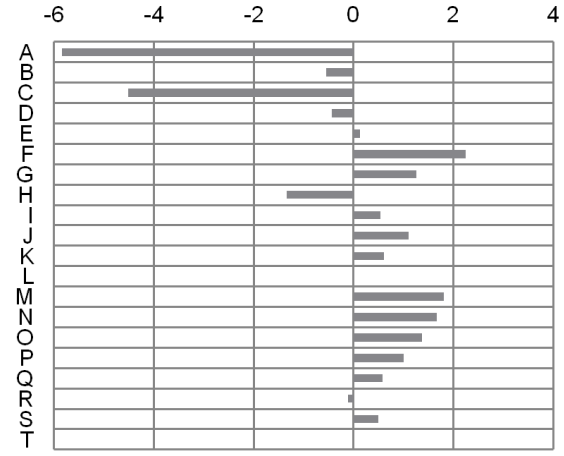

Poland, 2011-2005, N2

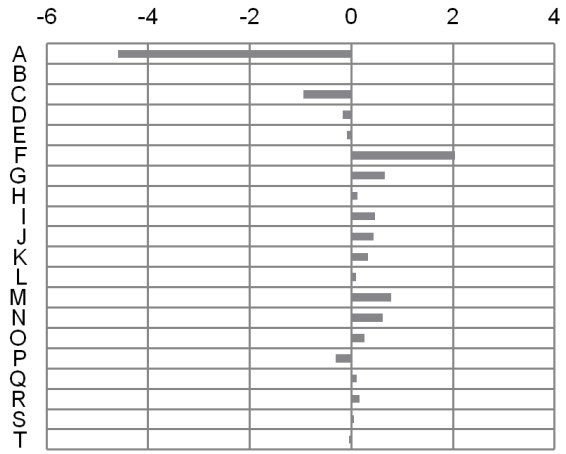

Note: See Annex for NACE sectoral codes.

Source: wiiw calculations based on Eurostat 
Figure 9: Structural change - shares in employment (in percentage points) NACE Rev. 2

Hungary, 2011-1995, N2

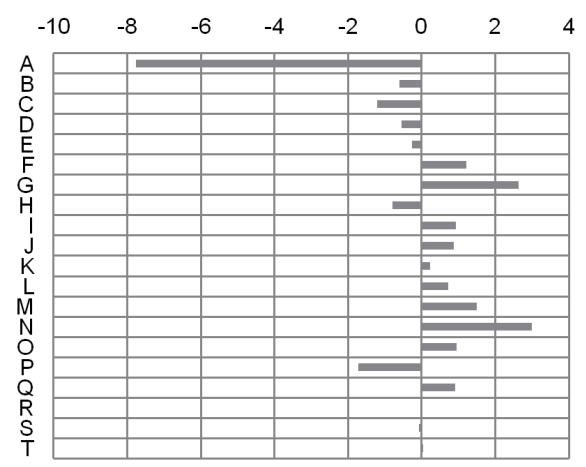

Slovenia, 2011-1995, N2

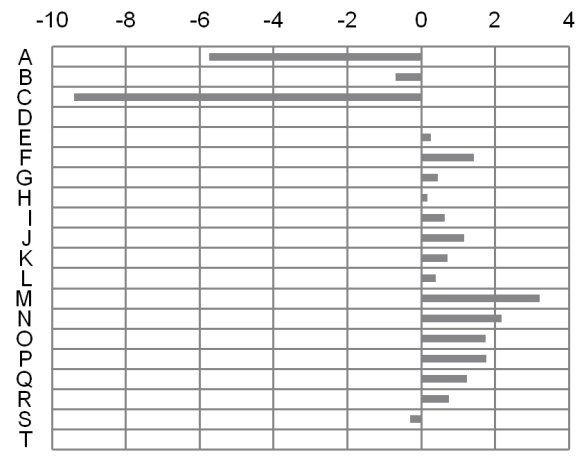

Bulgaria, 2011-1995, N2 (A10)

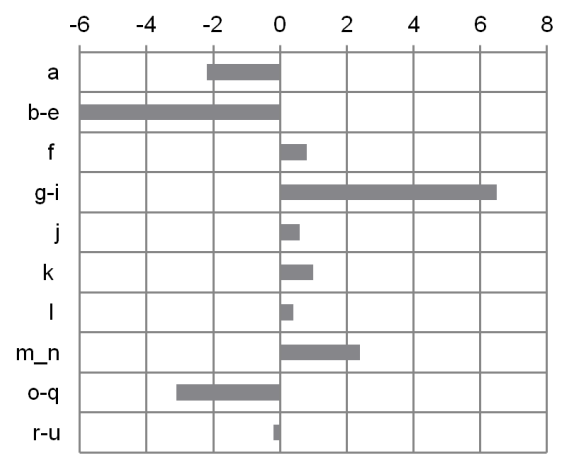

Slovakia, 2011-1995, N2

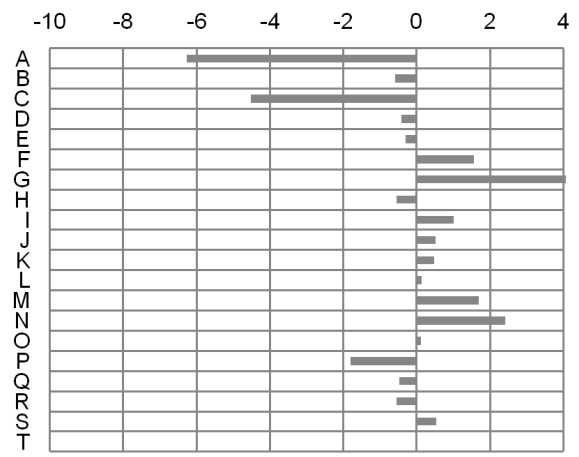

Lithuania, 2011-2000, N2

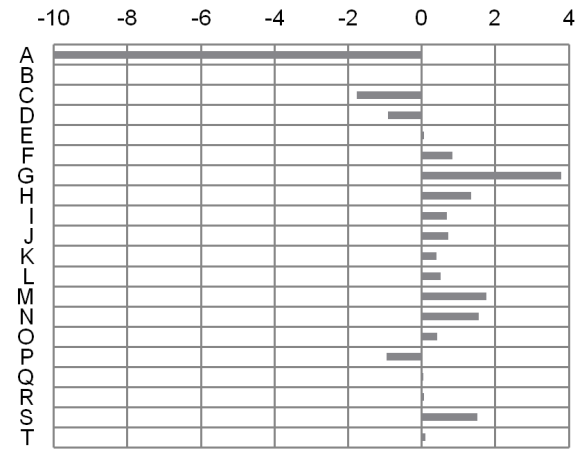

Romania, 2010-1996, N1 (A06)

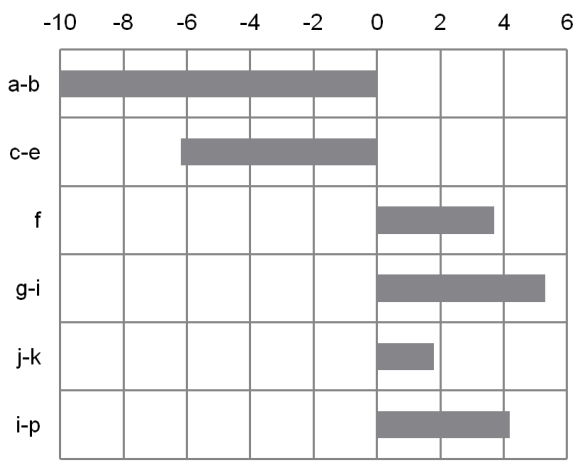


Cyprus, 2011-1995, N2

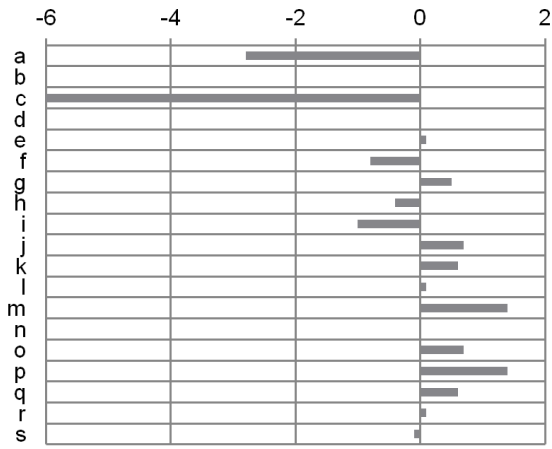

Malta, 2011-1995, N2

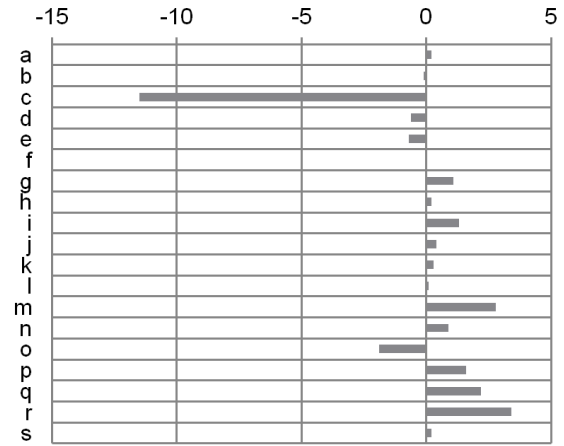

Figure 10: Structural change - shares in employment (in percentage points) NACE Rev. 2

Czech Republic, 2011-2008, N2

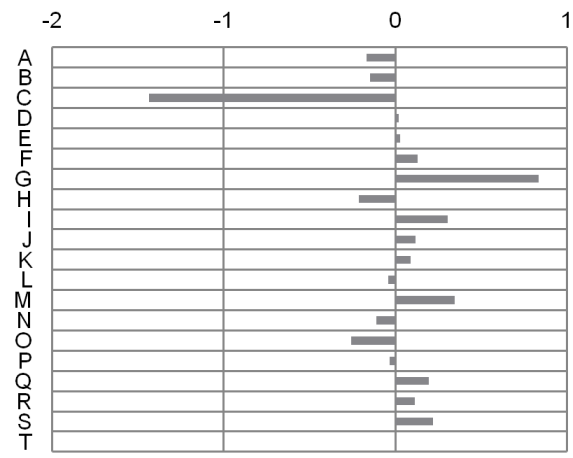

Estonia, 2011-2008, N2

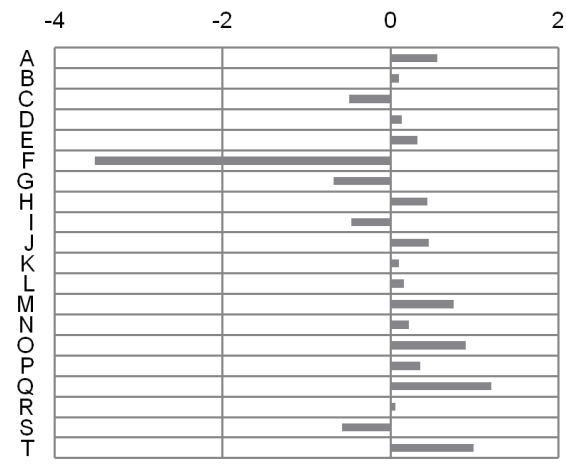

Note: See Annex for NACE sectoral codes.

Source: wiiw calculations based on Eurostat
Poland, 2011-2008, N2

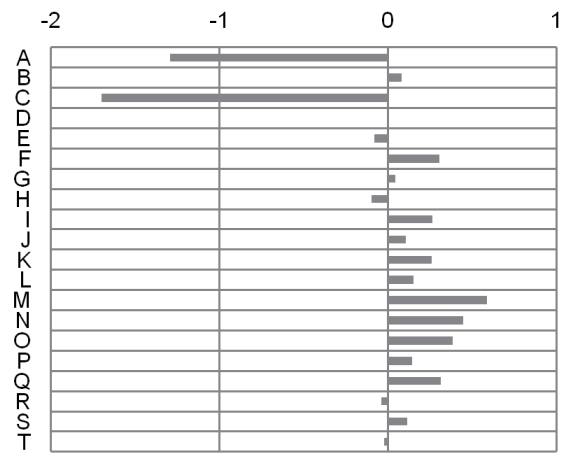

Latvia, 2011-2008, N2

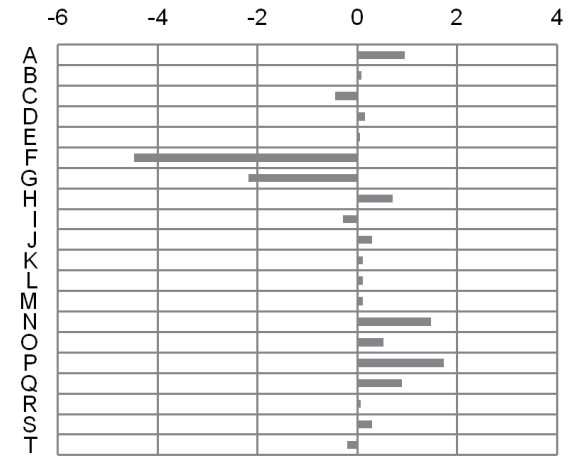


Figure 11: Structural change - shares in employment (in percentage points) NACE Rev. 2

Hungary, 2011-2008, N2

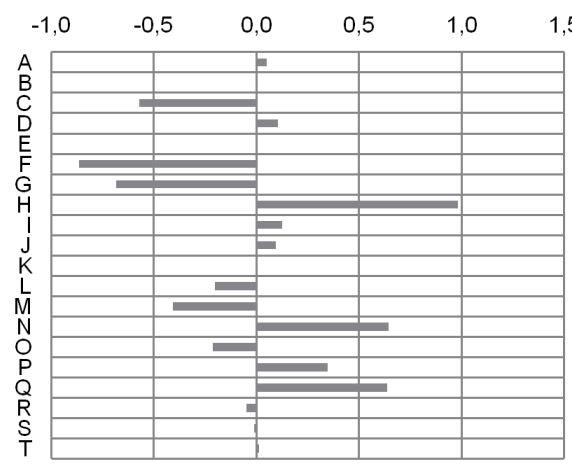

Slovenia, 2011-2008, N2

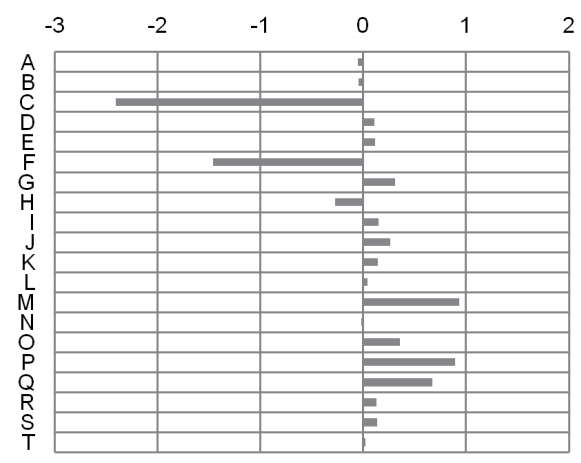

Bulgaria, 2011-2008, N2 (A10)

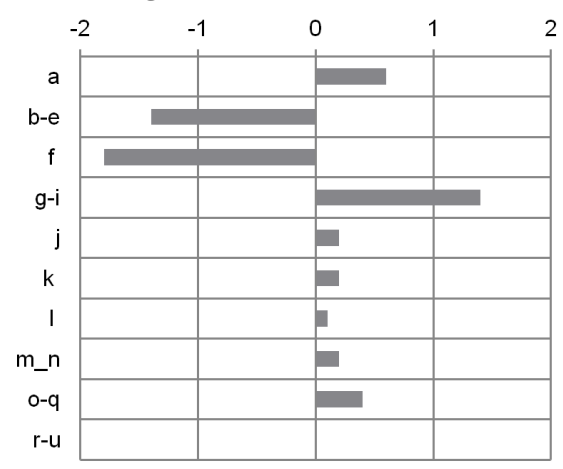

Slovakia, 2011-2008, N2

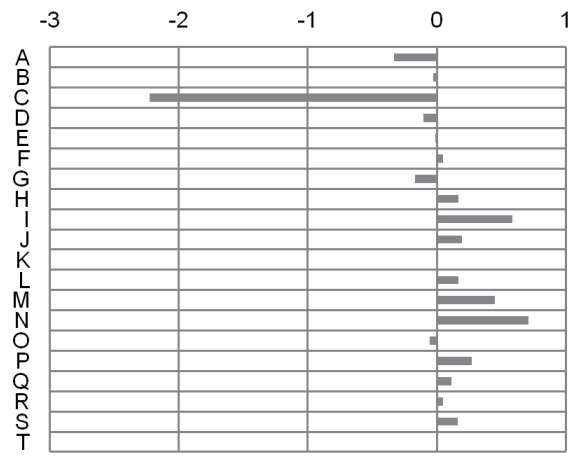

Lithuania, 2011-2008, N2

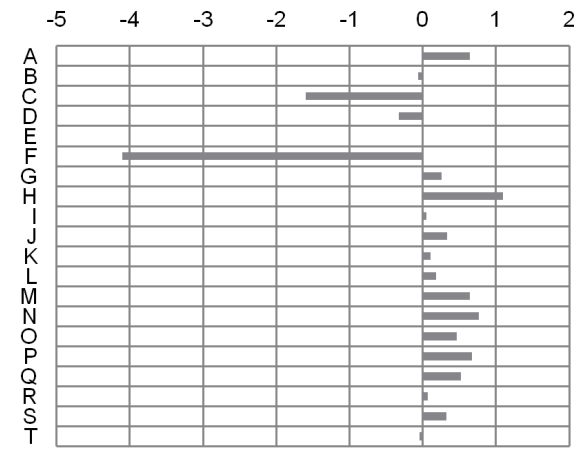

Romania, 2011-2008, N2

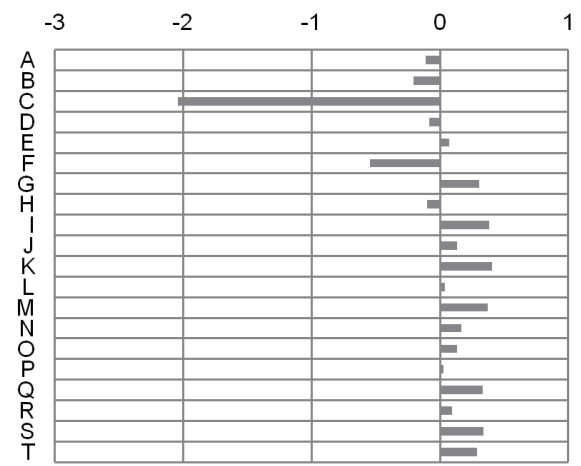


Cyprus, 2011-2008, N2

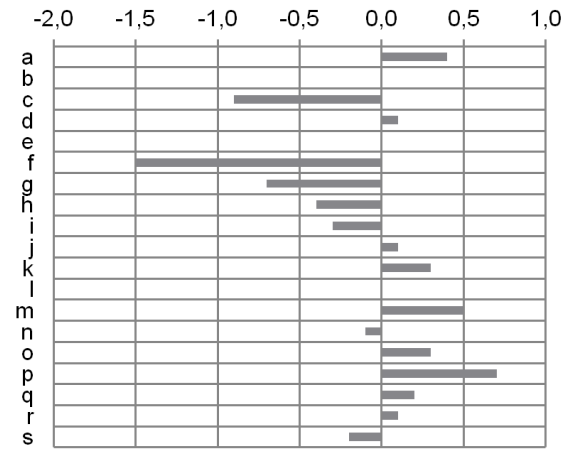

Malta, 2011-2008, N2

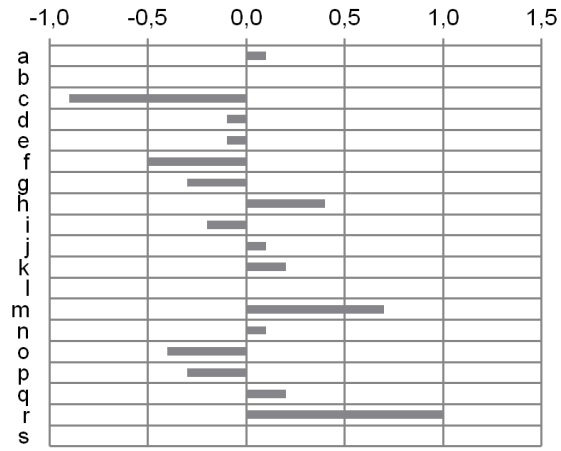

Note: See Annex for NACE sectoral codes.

Source: wiiw calculations based on Eurostat

\section{Structural change and effects on growth}

After the presentation of the above stylised facts regarding output and employment restructuring, the next step in our analysis is to evaluate the impact of structural changes on aggregate economic growth. For this purpose we shall use the frequently applied shift-share analysis in analogy with Timmer and Szirmai (2000), Fagerberg (2000), Peneder (2002), de Vries et al. (2012) and others. ${ }^{9}$ The shift-share analysis provides a convenient tool for investigating how aggregate (productivity) growth is linked to differential (productivity) growth performance at the sectoral level and what are the effects of the reallocation of labour between industries. It is particularly useful for the analysis of structural development patterns in a cross-country framework where data limitations prevent us from using more sophisticated econometric approaches. Using a similar notation as presented in Peneder (2002) and Havlik (2008), we decompose the aggregate growth of gross value added into three separate effects:

$$
\begin{gathered}
\operatorname{growth}\left(Y_{T}\right)=\frac{Y_{T, f y}-Y_{T, b y}}{Y_{T, b y}}= \\
\overbrace{\sum_{i=l}^{n} Y_{i, b y}\left(S_{i, f y}-S_{i, b y}\right)}^{\text {I: static shift effect }}+\overbrace{\sum_{i=l}^{n}\left(Y_{i, f y}-Y_{i, b y}\right)\left(S_{i, f y}-S_{i, b y}\right)}^{\text {II: dynamic shift effect }}+\overbrace{\sum_{i=l}^{n}\left(Y_{i, f y}-Y_{i, b y}\right) S_{i, b y}}^{\text {III: within growth effect }} \\
Y_{T, b y}
\end{gathered}
$$

Notes: $Y=$ gross value added (GDP); $b y=$ base year, $f y=$ final year; $T=\sum$ over industries $i ; S_{i}=$ share of industry $i$ in total employment.

\footnotetext{
${ }^{9}$ A decomposition of aggregate productivity growth in the total economy and manufacturing industry in the NMS was performed earlier by the present author (Havlik, 2008).
} 
The first structural component is calculated as the sum of relative changes in the allocation of labour across industries between the final year and the base year, weighted by the volume of the sector's output in the base year. This component is called the employment structural effect. It is positive/negative if industries with initially high levels of output (or labour productivity and usually also high capital intensity) attract relatively more/less labour resources over time and hence increase/decrease their shares in total employment. A positive employment structural change effect implies that labour shifts from low to higher output producing industries.

Second, dynamic shift effects are captured by the sum of interactions of changes in the employment shares and output growth of individual industries. If industries grow faster and increase their shares in total employment, the combined effect is a positive contribution to the overall output growth (of course, the same applies if industries are characterised by a simultaneous fall in output and employment shares). In other words, the larger the interaction term becomes, the more labour resources shift towards industries with faster growth. The interaction effect is, however, negative if industries with fast growing output cannot maintain their shares in total employment. The negative effect is larger when more industries with high output (or productivity) growth are faced with declining employment shares.

Finally, the 'within growth' effect corresponds to growth in aggregate output under the assumption that no structural shifts in labour have ever taken place and each industry has maintained the same share in total employment as in the base year.

We must, however, recall that the frequently observed near equivalence of the within growth effect and aggregate growth cannot be used as evidence against differential growth between industries. Even in the event that all positive and negative structural effects net each other out, much variation in output growth can be present at the lower level of activities. As output and productivity have a robust tendency to grow, the within growth effect is practically a summation over positive contributions only. Conversely, for each industry the sign of the contribution to both static and dynamic shift effects depends on whether labour shares have increased or decreased. The summation over all industries therefore collects positive and negative contributions, with the changes in labour shares offsetting each other. The labour shift effects are therefore meant to capture only that comparatively small increment to aggregate growth which is generated by the net difference in productivity performance of the shifting share of the labour resources. In short, offsetting effects of shifts in employment shares of industries with high and low levels of output, as well as high and low output growth, explain why shift-share analyses regularly fail to reveal substantial direct contributions of structural change to aggregate growth. 
Table 3: Shift-and-share analysis - longer-term patterns

\begin{tabular}{|l|c|c|c|c|}
\hline \multicolumn{1}{|c|}{ NMS } & Period & static shift & dynamic shift & within growth \\
\hline BU, N2 & $1996-2011$ & -0.378 & 0.029 & 8.134 \\
CZ, N2 & $1995-2011$ & -0.197 & -0.118 & 10.201 \\
EE, N2 & $1995-2011$ & -0.359 & -0.612 & 9.444 \\
HU, N2 & $1995-2011$ & -0.014 & -0.080 & 5.246 \\
LV, N2 & $2000-2011$ & -0.394 & -0.085 & 4.802 \\
LT, N2 & $2000-2011$ & -0.037 & 0.371 & 6.239 \\
PL, N2 & $2004-2011$ & -0.034 & 0.092 & 4.218 \\
RO, N1 & $1999-2010$ & 0.543 & 2.511 & 6.335 \\
SK, N2 & $1997-2011$ & -0.095 & -0.651 & 10.070 \\
SI, N2 & $1995-2011$ & -1.328 & -1.016 & 6.980 \\
CY, N2 & $1995-2011$ & -0.719 & 0.486 & 3.262 \\
\hline
\end{tabular}

Source: Own calculations based on Eurostat

Furthermore, it is important to recall that the majority of NMS have experienced an absolute fall in employment (at both aggregate and even more so in manufacturing industry) during the period covered, so that output growth was usually associated with a reduction of jobs. Employment cuts characterised developments in nearly all EU countries during the crisis period 2008-2011.

Our shift-and-share analysis starts with the period 1995-2011, for which in the majority of EU countries NACE Rev. 2 data are available in the A10 and A21 sectoral breakdown, respectively. Data on sectoral gross value added published by Eurostat refer to chain-linked volumes at 2005 reference prices; employment shares data are based on the number of employed persons as in the section above. The results show highly differentiated patterns across the individual EU countries (Table 3). Typically of all NMS (no data for Malta available), the within growth effect is positive and dominates the overall structural change (the Czech Republic and Slovakia are two outstanding examples). Growth within individual sectors thus by far dominates overall performance. ${ }^{10}$ In contrast, both static and dynamic shift effects are much smaller, frequently even negative - especially the former (with the sole exception of Romania). ${ }^{11}$ This means that employment shifts between sectors had a negative effect on overall GVA growth; the simultaneous shifts of output and employment between sectors had no unequivocal growth effects.

\footnotetext{
${ }^{10}$ Similar results for CEECs were found for the period 1995-2000 (Havlik, 2003). Peneder (2002) found similar results for West European EU countries in the period 1995-1999.

${ }^{11}$ Romanian data are available for a shorter period, only at NACE Rev. 1 classification.
} 
Figure 12: Shift-and-share growth decomposition

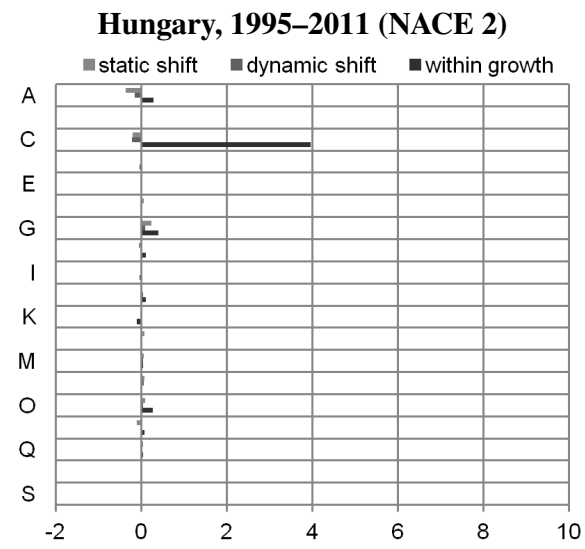

Czech Republic, 1995-2011 (NACE 2)

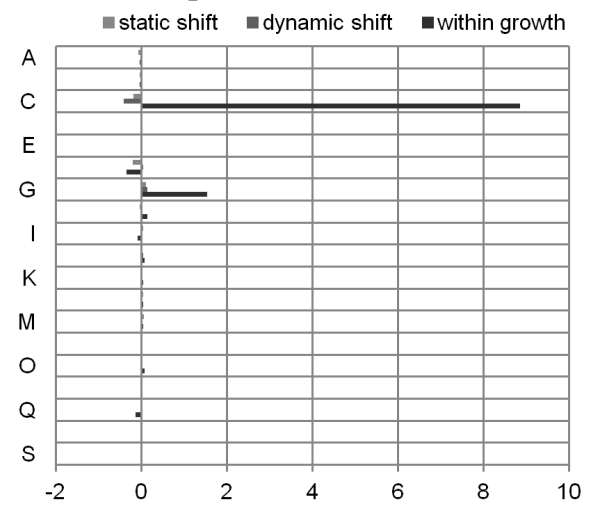

Slovakia, 1997-2011 (NACE 2)

Slovenia, 1995-2011 (NACE 2)
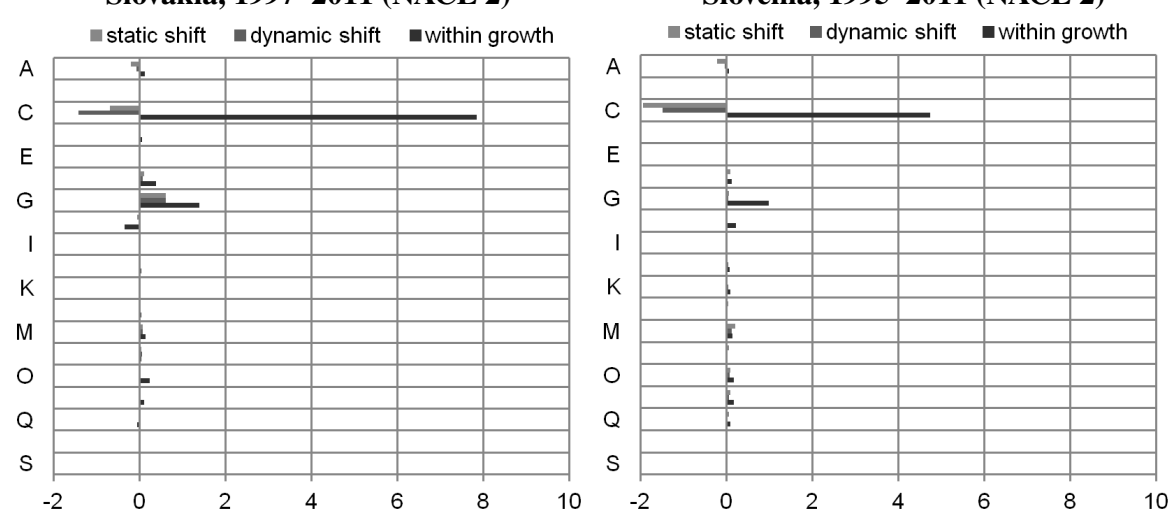

Note: See Annex for NACE sectoral codes.

Source: wiiw calculations based on Eurostat

Close inspection of the data shows that the positive 'within growth' component can be mostly attributed to manufacturing in both NMS and OMS; other sectors do not seem to play any outstanding role in this respect. In general, this effect is much larger in the NMS than in Western Europe; the shape of structural shifts in NMS is more similar (though larger) to some West European countries (e.g. Austria, Germany) than to Southern Europe. Figure 12 provides a more detailed stylised picture of characteristic longer-term restructuring patterns in selected NMS. ${ }^{12}$ It provides illustrative results for the countries with the biggest structural change among the NMS (the Czech Republic, Hungary, Slovakia and Slovenia; Bulgaria and especially Estonia would also belong to this group): without

${ }^{12}$ The remaining countries display much less clear restructuring patterns across individual sectors - see Appendix. 
the 'within growth' effect in manufacturing, the overall GVA increase would be much smaller. In all NMS, the manufacturing industry dominates the prevailing overall 'within growth' effect, in particular in the Czech Republic and in Slovakia. Another sector with a prevalently positive contribution to growth in most countries was trade.

Table 4: Shift-and-share analysis, 2008-2011

\begin{tabular}{|l|c|c|c|}
\hline \multicolumn{1}{|c|}{ NMS } & static shift & dynamic shift & within growth \\
\hline BU, N2 & -0.050 & 0.040 & -0.210 \\
CZ, N2 & -0.320 & 0.000 & 0.340 \\
EE, N2 & -0.270 & 0.110 & -0.700 \\
HU, N2 & -0.170 & 0.020 & 0.540 \\
LV, N2 & -0.590 & 0.240 & -1.230 \\
LT, N2 & -0.430 & 0.160 & -0.850 \\
PL, N2 & -0.280 & -0.080 & 1.490 \\
RO, N1* & 0.430 & -0.040 & -1.170 \\
SK, N2 & -0.500 & -0.030 & 0.070 \\
SI, N2 & -0.460 & 0.090 & -0.810 \\
CY, N2 & -0.220 & 0.090 & -0.370 \\
$* 2008-2010$ & & & \\
\hline
\end{tabular}

Source: Own calculations based on Eurostat

Presumably, the period of the recent crisis (2008-2011) must not only have had lasting effects on levels of economic activity and employment, but has also affected the sectoral structures of European countries and their growth patterns. In order to investigate these effects, we have performed the shift-and-share analysis for this period separately. Table 4 provides the aggregate results for individual EU countries; Figure 13 again shows details by sectors in selected 'characteristic' NMS. ${ }^{13}$ In the Czech Republic and in Slovakia (in contrast to Hungary and Slovenia), the manufacturing 'within growth' effect contributed positively to overall output growth. Another interesting feature is the generally positive contribution of construction in the Czech Republic compared to NMS peers.

The extent of structural shifts is again very much differentiated across individual EU countries. The overall growth effect is naturally much smaller owing to the shorter time period covering only four years, but - the crisis notwithstanding - it is not negative everywhere (Table 4). A positive 'static shift' (labour moving to 'traditional sectors') is recorded in Romania, Ireland and France. A positive 'within growth' effect (growth of sectoral value added) was recorded not only in Poland (the only EU country which did not experience negative growth during the crisis period), but also in the Czech Republic and in Slovakia. Explanations for these rather surprising results are provided by the more detailed sectoral decompositions shown in Figures 8. In the Czech Republic (and in Poland), both the manufacturing industry and trade determined the positive 'within growth' effect (in Slovakia it was just manufacturing).

${ }^{13}$ Data for the recent crisis period are more comparable: NACE Rev. 2 classification is available for all countries (except Romania). No data available for Malta. 
Figure 13: Shift-and-share growth decomposition

Hungary, 2008-2011 (NACE 2)

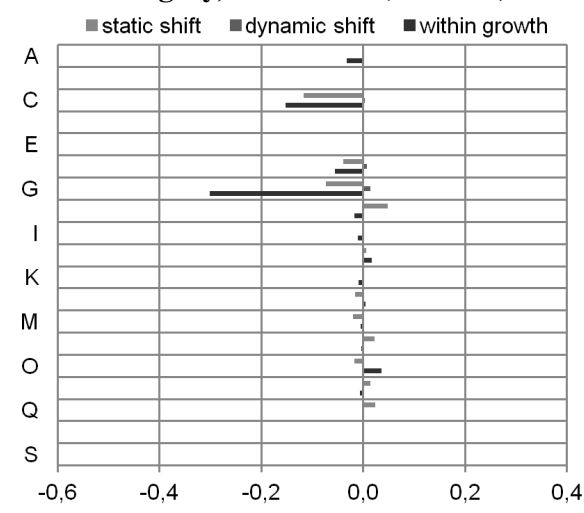

Slovakia, 2008-2011 (NACE 2)

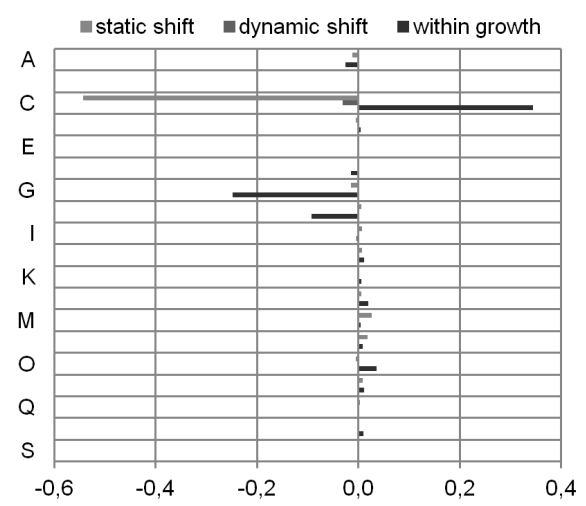

Czech Republic, 2008-2011 (NACE 2)

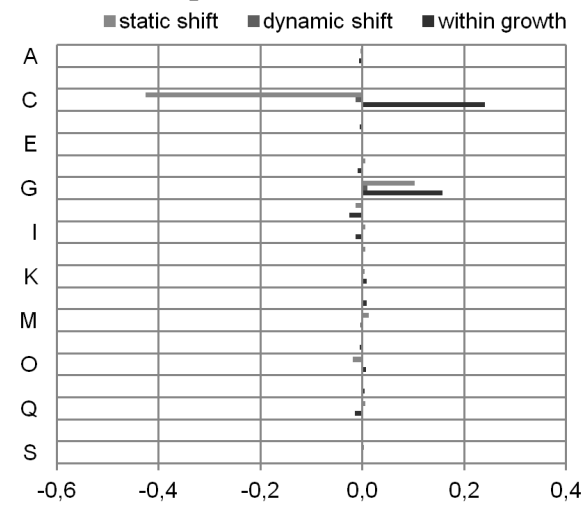

Slovenia, 2008-2011 (NACE 2)

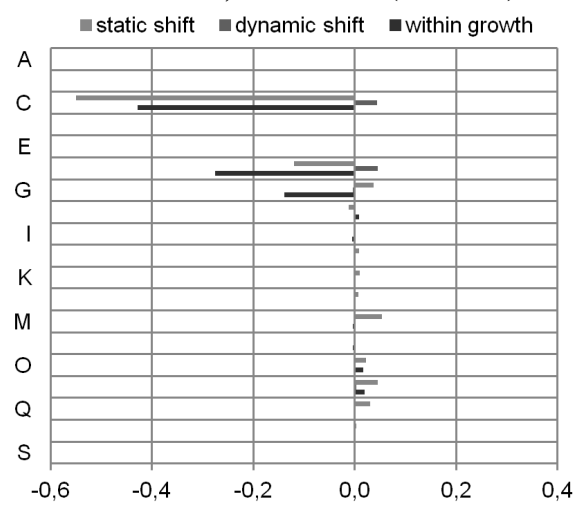

Note: See Annex for NACE sectoral codes.

Source: wiiw calculations based on Eurostat

\section{Conclusion}

The period of rapid industrial restructuring was over in most NMS by the end of the 1990s, although the pace of structural change in this group of countries has generally been higher than in the majority of OMS even thereafter. Patterns of structural change in terms of both output and employment have been very much differentiated, both across time and individual European countries. In general, structural changes have been more pronounced with regard to employment than output (implying large shifts in productivity performance), with broad shifts from agriculture and industry towards services. Especially Bulgaria, Romania and the Baltic States have experienced more structural change than the 
Czech Republic, Slovakia and Slovenia. Both groups of NMS and OMS behaved similarly with respect to restructuring during the whole period 1995-2011, as well as in the crisis sub-period 2008-2011. However, a certain revival of manufacturing in the latter period was observed in Hungary, Romania and the Baltic States (as well as in Germany and Ireland). The majority of NMS still have a larger manufacturing sector than the OMS (in terms of both output and employment shares).

A decomposition of value added growth using the shift-and-share analysis over the whole period 1995-2011 shows that the 'within growth' effect naturally dominates the overall structural change. This growth effect has again been much greater in the NMS than in the OMS. In this respect, NMS have also been more similar to EU-North (Austria, France, the Netherlands, Finland and Sweden). Sectors with initially large employment shares have suffered cuts in practically all EU countries and the structural growth effect was mostly negative. The overall positive 'within growth' effect can be attributed mostly to manufacturing.

Structural shifts during the crisis period 2008-2011 have had even more differentiated effects and, interestingly, these were not overwhelmingly negative. Positive 'within growth' effects were recorded in a number of EU countries (apart from Poland, this was also the case in the Czech Republic, Slovakia, Austria, Germany, France, the Netherlands and Sweden). Again, manufacturing and trade provided a key impetus for aggregate growth even in the period of crisis: a strongly positive 'within growth' effect in manufacturing and trade more than compensated declines in employment in these sectors, in particular in Austria and Sweden (the opposite occurred in Finland).

\section{References}

Baumol, W. J. (1967). Macroeconomics of Unbalanced Growth: The Anatomy of Urban Crisis. The American Economic Review, 57, 415-426.

de Vries, G. J., Erumban, A. A., Timmer, M. P. and Voskoboynikov, I. (2012). Deconstructing the BRICs: Structural transformation and aggregate productivity growth. Journal of Comparative Economics, 40, 211-227.

Dobrinsky, R. and Landesmann, M. (eds.). (1995). Transforming Economies and European Integration. Edward Elgar, Aldershot, UK, 86-115.

European Commission. (2011). EU industrial structure 2011. Trends and Performance, DG ENTR, Luxembourg.

Fagerberg, J. (2000). Technological progress, structural change and productivity growth: a comparative study. Structural Change and Economic Dynamics, 11(4), 393-412.

Hanzl-Weiss, D. and Landesmann, M. (2013). Structural adjustment and unit labour cost developments in Europe's periphery. In V. Astrov et al., Double-dip Recession over, yet no Boom in Sight. wiiw Current Analyses and Forecasts, 11. The Vienna Institute for International Economic Studies (wiiw), Vienna, March, 46-59.

Havlik, P. (2003). Restructuring of Manufacturing Industry in the Central and East European Countries. Prague Economic Papers, 1, 18-35. 
Havlik, P. (2005a). Structural Change, Productivity and Employment in the New EU Member States. wiiw Research Reports, 313, The Vienna Institute for International Economic Studies (wiiw), Vienna, January.

Havlik, P. (2005b). Central and East European Industry in an Enlarged European Union: Restructuring, Specialisation and Catching-Up. Économie Internationale, 102, 107-132. Havlik, P. (2008). Economic Restructuring in the New EU Member States and Selected Newly Independent States: Effects on Growth, Employment and Productivity. In R. Grinberg, P. Havlik and O. Havrylyshyn (eds). Economic Restructuring and Integration in Eastern Europe. Experiences and Policy Implications, Nomos, Baden-Baden, 47-72.

Havlik, P., Leitner, S. and Stehrer, R. (2012). Growth resurgence, productivity catching-up and labour demand in Central and East European Countries. In M. Mas and R. Stehrer (eds). Industrial Productivity in Europe. Growth and Crisis, Edward Elgar.

Landesmann, M. and Stehrer, R. (2002). The CEECs in the Enlarged Europe: Convergence Patterns, Specialization and Labour Market Implications. wiiw Research Reports, 286, The Vienna Institute for International Economic Studies (wiiw), Vienna, July.

Maddison, A. and van Ark, B. (1988). Comparisons of Real Output in Manufacturing. The World Bank, Washington, D.C.

McKinsey Global Institute. (2012). Manufacturing the future: The next era of global growth and innovation.

Peneder, M. (2002). Structural Change and Aggregate Growth. WIFO Working Papers, 182, Vienna.

Peneder, M. (2003). Industrial Structure and Aggregate Growth. Structural Change and Economic Dynamics, 14(4), 427-448.

Timmer, M. P. and Szirmai, A. (2000). Productivity growth in Asian manufacturing: the structural bonus hypothesis examined. Structural Change and Economic Dynamics, 11(4), 371-392.

Timmer, M. P., Inklaar, R., O’Mahony, M. and van Ark, B. (2010). Economic Growth in Europe. A Comparative Industry Perspective. Cambridge University Press.

van Ark, B., O'Mahony, M. and Timmer, M. P. (2012). Europe's productivity performance in comparative perspective: trends, causes and recent developments. In M. Mas and R. Stehrer (eds). Industrial Productivity in Europe. Growth and Crisis, Edward Elgar, 65-92.

Vidovic, H. (2002). The Services Sectors in Central and Eastern Europe. wiiw Research Reports, 289. The Vienna Institute for International Economic Studies (wiiw), Vienna, September.

wiiw (2012), wiiw Handbook of Statistics, The Vienna Institute for International Economic Studies (wiiw), Vienna. 


\section{Annex}

\section{Industry classifications}

N1 (NACE Rev. 1)

A Agriculture, hunting and forestry

B Fishing

C Mining and quarrying

D Manufacturing

E Electricity, gas and water supply

F Construction

G Wholesale, retail trade, repair motor veh. NT

$\mathrm{H}$ Hotels and restaurants NT

I Transport, storage and communications $\mathrm{T}$

$\mathrm{J}$ Financial intermediation $\mathrm{T}$

K Real estate, renting \& business activities NT

L Public admin., defence, compuls. soc. sec. NMS

M Education

NMS

N Health and social work NMS

O Oth. community, social \& personal serv. NT

P Private households with employed pers. NT

Q Extra-territorial organisations and bodies excluded
N2 (NACE Rev. 2)

A Agriculture, forestry and fishing

B Mining and quarrying

C Manufacturing

D Electricity, gas, steam and air cond.supply

E Water supply, sewerage, waste manag.,etc

F Construction

G Wholesale, retail trade, repair of motor veh. NT

$\mathrm{H}$ Transportation and storage $\mathrm{T}$

I Accommodation and food service activities NT

$\mathrm{J}$ Information and communication $\mathrm{T}$

$\mathrm{K}$ Financial and insurance activities $\quad \mathrm{T}$

L Real estate activities NT

M Professional, scientific and techn. activities T

$\mathrm{N}$ Administrative and support service activ. NT

O Public admin., defence, compuls. soc. sec. NMS

$\mathrm{P}$ Education NMS

Q Human health and social work activities NMS

$\mathrm{R}$ Arts, entertainment and recreation NT

$S$ Other service activities NT

T Activ. of househ.as employers \& for own use NT

U Activ. of extraterritorial organisat. \& bodies excluded

Note:

TS - Tradable Services

NTS - Non-tradable Services

$\mathrm{I}+\mathrm{J} \quad \mathrm{TS}-$ Tradable Services

$\mathrm{H}+\mathrm{J}+\mathrm{K}+\mathrm{M}$

NMS - Non-market Services

$\mathrm{G}+\mathrm{H}+\mathrm{K}+\mathrm{O}+\mathrm{P}$ NTS - Non-tradable Services

$\mathrm{G}+\mathrm{I}+\mathrm{L}+\mathrm{N}+\mathrm{R}+\mathrm{S}+\mathrm{T}$

$\mathrm{L}+\mathrm{M}+\mathrm{N} \quad \mathrm{NMS}-$ Non-market Services

$\mathrm{O}+\mathrm{P}+\mathrm{Q}$

\section{Country Codes and Abbreviations}

\begin{tabular}{llll}
\hline AL & Albania & RS & Serbia \\
BA & Bosnia and Herzegovina & RU & Russia \\
BG & Bulgaria & SI & Slovenia \\
CZ & Czech Republic & SK & Slovakia \\
EE & Estonia & TR & Turkey \\
HR & Croatia & UA & Ukraine \\
HU & Hungary & XK & Kosovo \\
KZ & Kazakhstan & & \\
LT & Lithuania & & \\
LV & Latvia & & \\
ME & Montenegro & CESEE & Central, East and Southeast Europe \\
MK & Macedonia & CIS & Commonwealth of Independent States \\
PL & Poland & NMS & New Member States \\
RO & Romania & SEE & Southeast Europe
\end{tabular}

